(Roč. 15). - S. 3-26. 2. Krajčová N. Pregraduálna príprava učitel’ov - stav a očakávania / Nadežda Krajčová // Učitel' na ceste k profesionalite : recenzovaný zborník vedeckých prác / N. Krajčová, V. Šutáková eds. - Prešov: FHPV PU a Škola plus, s.r.o. - S. 37-45. 3. Národný program výchovy a vzdelávania v Slovenskej republike [Electronic Resource]. Mode of access : URL : http://www.noveskolstvo.sk/upload/pdf/npvv.pdf 4. Programové vyhlásenie vlády SR z 25. novembra 1998 [Electronic Resource]. - Bratislava : Úrad vlády SR, 1998. - Mode of access : URL : http://www.vlada.gov.sk/ 5. Sústava študijných odborov. 1.1. Učitel'stvo, vychovávatel'stvo a pedagogické vedy [Electronic Resource]. Mode of access : URL : http://www.akredkom.sk/index.pl?tmpl=odbory 6. Uznesenie vlády SR 685/2000 z 30. augusta 2000 k návrhu koncepcie d'alšieho rozvoja vysokého školstva na Slovensku pre 21. storočie [Electronic Resource]. - Mode of access: URL : http://www.vlada.gov.sk/uznesenia/2000/0830/u_0685_2000.html 7. Vyhláška Ministerstva školstva SR z 26. januára 1996 o d'alšom vzdelávaní pedagogických pracovníkov // Zbierka zákonov. - 1996. - Čiastka 16. - Č. 42. - S. 416-418. 8. Vyhláška Ministerstva školstva SR z 26. januára 1996 o odbornej a pedagogickej spôsobilosti pedagogických pracovníkov // Zbierka zákonov. - 1996. - Čiastka 16. - C̆. 41. - S. 398-415. 9. Vysokoškolské vzdelávanie učitel'ov : vývoj, analýza, perspektívy / B.Kosová [et al.]. - Banská Bystrica : Pedagogická fakulta Univerzity Mateja Bela, 2012. - 143 s. 10. Zákon č. 317/2009 z 24. júna 2009 o pedagogických zamestnancoch a odborných zamestnancoch a o zmene a doplnení niektorých zákonov // Zbierka zákonov. - Čiastka 113. - S. 2334-2361.

УДК $378.22+377.35+001$

Ірина Княжева

\title{
ПРОБЛЕМА ПРОФЕСІЙНОЇ ПІДГОТОВКИ ВИКЛАДАЧІВ ВИЩОЇ ШКОЛИ ДО ПЕДАГОГІЧНОЇ ДІЯЛЬНОСТІ В УМОВАХ МАГІСТРАТУРИ В НАУКОВИХ ДОСЛІДЖЕННЯХ
}

Княжева І. А.Проблема професійної підготовки викладачів вищої школи до педагогічної діяльності в умовах магістратури в наукових дослідженнях.

У статті проведено аналіз стану проблеми професійної підготовки викладачів вищої школи до педагогічної діяльності в умовах магістратури в теорії і практиці вищої освіти. Особливу увагу приділено висвітленню актуальних проблем професійної підготовки майбутніх фахівців у галузі дошкільної освіти, зокрема викладачів педагогічних дисциплін спеціальності «Дошкільна освіта».

Ключові слова: професійна підготовка, майбутні викладачі, магістратура, педагогічні дисципліни, вища школа.

Княжева И. А. Проблема профессиональной подготовки преподавателей высшей школы к педагогической деятельности в условиях магистратуры в научных исследованиях.

В статье проведен анализ проблемы профессиональной подготовки преподавателей высшей школы к педагогической деятельности в условиях магистратуры в теории и практике высшего образования. Особое внимание уделено освещению актуальных проблем профессиональной подготовки будущих специалистов в области дошкольного образования, в том числе преподавателей педагогических дисциплин специальности «Дошкольное образование».

Ключевые слова: профессиональная подготовка, будущие преподаватели, магистратура, педагогические дисциплины, высшая школа. 
Knyazheva I. A. Problem of professional preparation of teachers of higher school to pedagogical activity in the conditions of master's degree education in scientific researches.

In the article the analysis of problem of professional preparation of teachers of higher school to pedagogical activity in the conditions of master's degree education in a theory and practice of higher education is conducted. The special attention is spared illumination of issues of professional preparation of future specialists in area of preschool education, including pedagogical disciplines teachers of speciality «pre-school education».

Key words: professional preparation, future teachers, magistracy, pedagogical disciplines, higher school.

Оскільки, відповідно до вимог Болонського процесу, магістратура є важливою сходинкою в підготовці висококваліфікованих фахівців, розуміння необхідності науково обгрунтованої підготовки викладачів вищої школи зумовило науковий інтерес вітчизняних і зарубіжних дослідників до різноманітних аспектів підготовки магістрів.

Уперше проблема підготовки викладачів вищої школи через аспірантуру, докторантуру, систему перепідготовки і підвищення кваліфікації стала порушуватись у другій половині XX століття в дослідженнях І. Автухова, А. Алексюка, Б. Ананьєва, С. Архангельського, В. Бондаря, С. Василейського, С. Зінов'єва, З. Єсаревої, І. Ісаєва, I. Кобиляцького, Н. Кузьміної, В. Сластьоніна, Р. Хмелюк та ін. Нині вона розглядається у працях Л. Артемової, Н. Батечко, О. Безлюдного, В. Береки, С. Вітвицької, Б. Вульфської, О. Гури, В. Жукова, Е. Карпової, А. Кузьмінського, К. Левківського, В. Лугового, В. Сенашенко, С. Сисоєвої, Г. Падалки та ін.

У зарубіжній теорії окремі питання, пов'язані 3 педагогічною підготовкою викладацьких кадрів для вишів, висвітлено в публікаціях Э. Джелли, А. Гроплея, К. Кнеппера, Ж. де Ландсер, Р. Лалле, Ж. М. Леклерк, Ж. Руэ та ін.

Метою статmі $\epsilon$ аналіз стану проблеми професійної підготовки викладачів вищої школи до педагогічної діяльності в умовах магістратури в теорії і практиці вищої освіти.

Дослідження специфіки підготовки викладачів у зарубіжних країнах здійснено в наукових працях С. Бурдіної, О. Джуринського, Н. Костіної, Н. Нікандрова, Л. Пуховської, Ю. Сорокопуд та ін. У них виявлено, що попри присутні в кожній країні національні особливості, загальними рисами організації професійної підготовки викладачів вищої школи для більшості країн Західної Європи $є$ наявність індивідуальних (через прикріплення до викладачів-менторів) і колективних форм, що реалізуються в докторантурах та спеціально створених центрах на базі університетів.

У наукових працях вітчизняних дослідників визначено особливості підготовки магістрантів до управлінської діяльності в різних професійних галузях, зокрема: військово-соціальній (О. Бойко, Т. Мацевко, І. Чистовська), економічній (Р. Гейзерська та ін.), аграрній (О. Заболотний, О. Малюга), музичного мистецтва (О. Єременко), освітній (В. Берека, А. Свєтлорусова) тощо.

Низка наукових праць спрямована на дослідження професійної підготовки майбутніх викладачів вищих технічних навчальних закладів у різних іiі аспектах: формування професійно-педагогічної компетентності (О. Жигалова, В. Іванов, А. Кірсанов, І. Кривчанський), професійного самоусвідомлення (О. Завалевська), перспективи використання інноваційних технологій (С. Дворецький, А. Іванов).

Різні аспекти проблеми особистісного зростання майбутніх викладачів в умовах магістратури висвітлено в дисертаційних дослідженнях Ю. Ірхіної (формування професійної толерантності майбутніх викладачів вищої школи), О. Коваль 
(формування професійно-моральних цінностей, зокрема професійної гордості, наполегливості, честі, професійно-морального досвіду).

Визначено педагогічні умови, що забезпечують ефективність формування потенціалу професійного саморозвитку в майбутніх викладачів вищої школи у процесі магістерської підготовки (Р. Цокур), формування їхнього професійнопедагогічного іміджу (В. Ісаченко), розвиток професійної самосвідомості (I. Донченко).

Розроблена педагогічна технологія формування полікультурної компетенції магістрів у вищих педагогічних навчальних закладах (Л. Воротняк), педагогічні умови формування педагогічної культури майбутнього викладача вищої школи в умовах магістратури (С. Чорна), організаційно-педагогічні основи інваріантної підготовки викладача вищої школи (А. Бусигіна).

Так, С. Чорною було висвітлено особливості професійної підготовки магістрантів, що сприяли успішному формуванню педагогічної культури, а саме: складником навчальних програм магістерської підготовки є оволодіння методологією педагогічної науки, логікою та методами педагогічних досліджень; навчання в магістратурі на базі вищої освіти дає змогу грамотно прогнозувати, моделювати педагогічну діяльність, що є запорукою педагогічної культури магістра, засвоєння ним ii особливих цінностей; науково-дослідна робота в магістратурі - це не тільки необхідний атрибут професійної підготовки майбутніх викладачів, вона $\epsilon$ професійним обов'язком, що вимагає постійного професійного саморозвитку, необхідних дослідницьких компетенцій, без яких неможливо сформувати педагогічну культуру [10, с. 16].

Проблема забезпечення якості підготовки магістрантів педагогічного університету до науково-дослідницької діяльності стала предметом наукових пошуків I. Батракової, 3. Єсаревої, В. Лаптєва, Г. Матушанського, Ю. Солянікова та ін.

Професійну підготовку магістрантів педагогічних університетів до організації кредитно-модульного навчання досліджено Н. Оськіною [7]. Отримані в досліджені дані дозволили стверджувати, що орієнтація змісту професійної підготовки магістрантів на організацію кредитно-трансферної системи освіти, озброєння їх уміннями та навичками організації кредитно-модульного навчання та залучення до самопроектувальної діяльності, що забезпечить свідоме ставлення до власної професійно-педагогічної позиції, сприятиме формуванню професійно-педагогічної компетентності студентів магістратури педагогічних університетів до організації кредитно-модульного навчання [7].

У межах започаткованого у вітчизняній науці Н. Гузій напряму дослідження основ професіоналізму викладачів вищої школи, здійснено дослідження М. Супрун [8], у якому визначено педагогічні умови оптимізації процесу формування основ професіоналізму майбутнього викладача вищої школи у процесі магістерської підготовки.

Лише в одиничних працях досліджено особливості професійного становлення викладачів педагогічних дисциплін. Серед них робота I. Мазур [5], де розглянуто формування професіоналізму майбутнього викладача педагогіки у процесі професійної підготовки, визначеного як системну характеристику особистості, що $є$ сукупністю і результатом сформованості професійної компетентності та майстерності, професійно-педагогічної культури, індивідуальних професійно-важливих якостей та здібностей, забезпечує ефективність і якісну організацію професійної діяльності, досягнення вершин у професійному розвиткові. Доведено, що означений процес ефективно відбуватиметься за умови побудови професійно-педагогічної підготовки на 
засадах педагогічної акмеології; активізації комунікативної взаємодії в системах «викладач-студент» та «студент-студент» у соціокультурному просторі педагогічного університету; методологізації та педагогічного спрямування науково-дослідної діяльності майбутнього викладача.

У роботі обгрунтовано, що організація педагогічного процесу вишу на акмеологічних засадах дозволяє спрямувати професійну підготовку на розвиток професіоналізму майбутнього викладача, комплексно здійснити процедуру цілепокладання його особистісно-професійного саморозвитку, реалізувати технологічний підхід в організації освіти, задіяти механізми професійного самовизначення, самоствердження, самореалізації, створення професійного образу «Я» в контексті самовираження особистості у професії викладача педагогіки [5, с. 11].

Формування проективних умінь у майбутніх викладачів педагогіки в умовах магістерської підготовки здійснене в дисертаційному дослідженні Н. Тітаренко [9]. У його межах доповнено й уточнено цілі навчання магістрантів, обгрунтовано необхідні для їх досягнення методи і форми навчання, проаналізовано структуру та функції дидактико-методичних комплексів (зокрема підручників), можливості їх проектування як педагогічних систем. У спроектованій автором моделі змісту навчання виокремлено блоки знань про сутність і функції підручника (компонентів дидактико-методичного комплексу), типологію структур підручника, сутність та процес педагогічного проектування, методи системного аналізу i моделювання, нормативні вимоги до обсягу та форми навчальних видань для вищої школи, галузевих стандартів, програм із фахових навчальних предметів, фундаментальні знання відповідної науки та блок проективних умінь (діагностичних, моделювання, інформаційних, організаційних), необхідних для створення навчально-методичного забезпечення навчального процесу вишу [9]. Запропонована автором технологія формування вмінь магістрантів проектувати підручники для вищих навчальних закладів є вагомим внеском щодо актуальної проблеми, пов'язаної 3 підвищенням вимог до методичної підготовки викладачів вишів.

С. Вітвицькою [1] визначені шляхи підвищення ефективності підготовки магістрів до педагогічної діяльності в умовах ступеневої освіти, а саме: забезпечення спадкоємності та наступності в підготовці педагогів різних освітньо-кваліфікаційних рівнів; оновлення змісту, методів підготовки студентів магістратури; встановлення доцільного зіставлення змістового та практично-діяльнісного компонентів педагогічної підготовки випускників класичних i педагогічних університетів відповідних освітньо-кваліфікаційних рівнів; спрямування навчально-виховного процесу на формування готовності майбутніх фахівців до інноваційної педагогічної діяльності та розвиток особистісних якостей; цілеспрямоване формування культури майбутнього вчителя, розширення його світогляду; формування в майбутніх фахівців інтересу до професійно-педагогічних знань, педагогічної спрямованості; оволодіння практичними навичками й уміннями застосовувати знання в нестандартних ситуаціях, озброєння особистісно зорієнтованими технологіями навчання i виховання, організація проблемного навчання та творчого пошуку розв'язання проблем; забезпечення випереджувального характеру підготовки педагогічних кадрів, оптимального поєднання професійно-педагогічної, фундаментального та соціальногуманітарного складників; ліквідація розриву між змістом педагогічної освіти і досягненнями педагогічної науки та практики, здійснення наукового супроводу інноваційних технологій; використання новітніх педагогічних, інформаційних та комп'ютерних технологій та створення нового покоління засобів навчання; удосконалення системи відбору молоді на педагогічні спеціальності тощо [1, с. 29]. 
Цілісна система підготовки майбутніх викладачів вищої школи в умовах магістратури, результатом якої $\epsilon$ формування їхньої психолого-педагогічної компетентності, запропонована О. Гурою [2]. Структура означеної компетентності представлена змістовим, діяльнісним (професійні знання, вміння, навички) та особистісним (властивості, здібності та якості) компонентами, а також механізмами і процесами їх узагальнення та вияву. Автором доведено, що поєднання цих складників здійснюється на основі самосвідомості, яка характеризується рефлексивним рівнем свого розвитку і виявляється в усвідомленні педагогом своєї професійної діяльності, самого себе як суб'єкта діяльності та професіонала.

Професійна діяльність педагога вищої школи, на думку О. Гури, передбачає: дослідження явищ об'єктивної дійсності, аналіз, синтез та їх генералізацію для подальшого обгрунтування, оформлення і викладання в контексті власного наукового підходу або теорії у вигляді наукового знання; єдність викладання навчальної дисципліни і наукової діяльності; керівництво навчально-пізнавальною діяльністю студентів за допомогою логіки викладеної науки, іiі теорії, перспектив розвитку та наявних наукових проблем; навчання методів роботи в лабораторіях, використання технічних засобів навчання, методик спостереження й експерименту; керівництво, стимулювання самостійної роботи студентів; сприяння розвитку їх загальнолюдських властивостей, світогляду; формування і розвиток професійних якостей майбутніх спеціалістів тощо.

Здійснивши узагальнення сучасних підходів до створення професіограми викладача вищої школи та $з$ огляду на сучасні вимоги до його підготовки, науковець розробив і апробував професіограму викладача ВНЗ як еталонну (нормативну) модель педагога-спеціаліста. Вона, як модель кінцевого результату підготовки фахівця у ВНЗ, $\epsilon$ основою кваліфікаційної характеристики, відповідно до якої розробляються навчальні плани і програми, зміст та методи професійної підготовки. Науковець пропонує виокремлення у професіограмі двох основних складників: суб'єктивної характеристики педагога вищої школи i нормативної характеристики його професійної діяльності. Перший складник містить базові знання в галузі теорії і практики, базові вміння та панівні підсистеми професійних якостей (організаційні, комунікативні, експресивні, професійного мислення і професійної спрямованості), а другий- основні види діяльності викладача вищої школи (навчальна, наукова, методична, організаційно-виховна) та завдання до них [2].

У низці досліджень (Н. Кузьміна, Н. Соловова та ін.) вказується на те, що специфіка викладацької діяльності полягає в поєднанні кількох іiї основних видів, а саме - педагогічної, наукової і методичної. О. Гура [2] наголошує, що специфіку діяльності викладача вищої школи зумовлює єдність педагогічної і наукової діяльності. Це дає змогу в педагогічному процесі не тільки оперувати відомими фактами і науковими знаннями, а й новими, створеними в межах власної наукової роботи.

Специфіка підготовки магістрів педагогічної освіти за спеціальністю «Дошкільна освіта» досі лишається практично не дослідженою. Окремі іiі аспекти подано в науковому доробку Л. Артемової (зміст та інтерактивні технології ступеневої освіти), А. Богуш (проблеми формування мовної особистості педагога), І. Дичківської (інноваційні технології ступеневої освіти), Т. Поніманської (підготовка фахівців 3 дошкільної освіти за кредитно-модульною системою організації навчального процесу) та інших вітчизняних науковців. Ця проблема стала спеціальним предметом лише кількох досліджень. Так, триває дослідження Л. Козак [3] стосовно підготовки майбутніх викладачів дошкільної педагогіки і психології до інноваційної професійної 
діяльності, результатом якого автор визначає формування відповідної компетентності. Дослідниця стверджує, що формування компетентності викладача дошкільної педагогіки і психології стосовно здійснення інноваційної професійної діяльності відбуватиметься ефективно за певних організаційно-методичних умов, а саме: позитивне ставлення до інноваційної професійної діяльності; стійкий пізнавальний інтерес до педагогічних інновацій як результату усвідомленого вибору майбутньої професійної діяльності; потреба у вивченні інноваційного педагогічного досвіду; розуміння можливостей i обмежень інноваційної професійної діяльності; забезпечення професійної підготовки технологіями, методами та формами навчання, які забезпечують формування інтересу до інноваційної діяльності, ініціювання та підтримку педагогічної творчості майбутніх викладачів, спрямовують на пошуководослідницьку діяльність; реалізація підготовки у формі проектної та навчальноігрової діяльності, яка охоплює всі структурні компоненти інноваційної діяльності викладача та забезпечує ту рольову поведінку, яка згодом буде визначальною у його майбутній професійній діяльності; розвиток рефлексивних умінь [3, с. 238].

У контексті проблеми професійної підготовки магістрантів спеціальності «Дошкільна освіта» виконано дослідження російських науковців І. Лавринець [4] i Н. Морєвої [6].

Так, І. Лавринець [4] звертається до з'ясування ролі педагогічних задач як засобу розвитку професійної самостійності майбутніх викладачів дошкільної педагогіки і психології. Вибір критеріальних педагогічних задач як основного засобу розвитку професійної самостійності пояснюється автором їх функціональним навантаженням, а саме: забезпеченням орієнтації майбутніх викладачів у сенсах наукової інформації для самостійної побудови педагогічної діяльності й оволодіння способами постановки педагогічних завдань; досягненням узгодженості якостей нормативності i креативності в самостійній діяльності майбутнього викладача; осмисленням майбутніми викладачами власних професійних намірів та можливостей; розвитком педагогічної рефлексії.

Метою дослідження Н. Морєвої [6] була розробка концепції та процесуальної моделі підготовки викладачів коледжів 3 дошкільної педагогіки і психології до професійної діяльності, що визначає способи, послідовність конструювання змісту і педагогічної технології з урахуванням сучасних тенденцій удосконалення підготовки педагогічних кадрів. Її результатом, за дослідницьким задумом, має стати освоєння професійно-педагогічної діяльності, оволодіння системою професійних компетенцій, становлення педагогічної культури та майстерності викладача дошкільної педагогіки і психології.

Автором обгрунтовано систему принципів, що реалізуються в означеній технології: побудови технології, що дозволяє представити ii як дидактичний конструкт (концептуальності, відтворюваності, конкретності); принципів навчання, які, на думку дослідниці, сприяють інтенсифікації та оптимізації процесу навчання в межах створеної технології. У роботі структуровано зміст і виявлено переваги інтеграції навчальних дисциплін предметної підготовки викладачів педагогічних коледжів дошкільного профілю 3 урахуванням розроблених принципів, що, переконана дослідниця, дозволяють здійснити єдиний, цілісний, безперервний процес навчання майбутніх фахівців у контексті становлення педагогічної культури, майстерності й оволодіння системою професійних компетенцій [6].

Отже, за останні два десятиріччя, коли була відроджена система магістратури і відбувся процес масової реорганізації педагогічних інститутів у педагогічні університети, проблема підготовки викладачів для вищої школи стала особливо 
актуальною. Уведення ступеневої вищої освіти, становлення магістратури як форми підготовки майбутніх викладачів стало одним із напрямів оновлення системи підготовки висококваліфікованих науково-педагогічних кадрів, оскільки згідно 3 чинним законодавством викладацькі посади можуть обіймати тільки особи, які мають повну вищу освіту і пройшли спеціальну педагогічну підготовку.

Специфікою магістерської підготовки сучасного викладача вищої школи $\epsilon$ необхідність поєднання науково-дослідної функції, що вимагає здатності до активних досліджень у тій галузі науки, у межах якої він викладає, й освітньо-професійної, що передбачає методичну підготовку до викладання певної навчальної дисципліни. Таке поєднання покликано усунути наявну суперечність, за якою необхідним і достатнім для викладача вищої школи вважається здобуття наукового ступеня в певній предметній галузі (наукова діяльність), а підготовка до викладацької діяльності відходить на другий план.

Перспективу подальших досліджень убачаємо у з'ясуванні специфіки методичної підготовки майбутніх викладачів педагогічних дисциплін спеціальності «Дошкільна освіта».

1. Вітвицька С. С. Теоретичні і методичні засади педагогічної підготовки магістрів в умовах ступеневої освіти : автореф. дис. на здобуття наук. ступеня д-ра пед. наук : спец. 13.00.04 «Теорія і методика професійної освіти» / С. С. Вітвицька. Житомир, 2011. - 42 с. 2. Гура О. І. Психолого-педагогічна компетентність викладача вищого навчального закладу: теоретико-методологічний аспект: [монографія]/ О. І. Гура. - Запоріжжя : ГУ «ЗІДМУ», 2006. - 332 с. З. Козак Л. В. Підготовка майбутніх викладачів дошкільної педагогіки і психології до інноваційної професійної діяльності : концептуальні підходи / Л. В. Козак // Педагогічний дискурс. - 2013. Випуск 14. - С. 234-239. 4. Лавринец И. А. Педагогические задачи как средство развития профессиональной самостоятельности у будущих преподавателей дошкольной' педагогики и психологии : дис. ... кандидата пед. наук : 13.00.08 / Лавринец Ирина Александровна. - Волгоград, 2002. - 242 с. 5. Мазур Н. I. Формування професіоналізму майбутнього викладача педагогіки у процесі професійної підготовки : автореф. дис. ... на здобуття наук. ступеня канд. пед. наук : спец. 13.00.04 «Теорія і методика професійної освіти»/ Н. І. Мазур. - Кіровоград, 2010. - 20 с. 6. Морева Н. А. Конструирование содержания и технология подготовки преподавателей дошкольной педагогики и психологии : дис. ... доктора пед. наук : 13.00.08 / Морева Наталья Александровна. - М, 2009. - 406 с. 7. Оськіна Н. О. Підготовка магістрантів педагогічних університетів до організації кредитномодульного навчання: автореф. дис. на здобуття наук. ступеня канд. пед. наук : спец. 13.00.04 «Теорія і методика професійної освіти»: 13.00.04 / Н. О. Оськіна. - Одеса, 2011. - 20 с. 8. Супрун М. В. Формування основ професіоналізму майбутнього викладача вищої школи в процесі магістерської підготовки : автореф. на здобуття наук. ступеня канд. пед. наук : спец. 13.00.04 «Теорія та методика професійної освіти» / М. В. Супрун. - Вінниця, 2012. - 21 с. 9. Тітаренко Н. Ю. Формування проективних умінь у майбутніх викладачів педагогіки в умовах магістерської підготовки : автореф. дис. на здобуття наук. ступеня канд. пед. наук : спец. 13.00.04 «Теорія і методика професійної освіти»/ Н. Ю. Тітаренко. - К., 2011. - 20 с. 10. Чорна С. С. Формування педагогічної культури майбутнього викладача вищої школи в умовах магістратури : автореф. дис. на здобуття наук. ступеня. канд. пед. наук : спец. 13.00.04 «Теорія і методика професійної освіти»/ С. С. Чорна. Запоріжжя, 2008. - 20 c. 